\title{
Annual variation in neustonic micro- and meso-plastic particles and zooplankton in the Bay of Calvi (Mediterranean-Corsica)
}

\author{
Amandine Collignon ${ }^{\mathrm{a}, \mathrm{b}, *}$, Jean-Henri Hecq ${ }^{\mathrm{a}, \mathrm{b}}$, François Galgani ${ }^{\mathrm{c}}$, France Collard ${ }^{\mathrm{a}}$, Anne Goffart ${ }^{\mathrm{a}, \mathrm{b}}$
}

\author{
a MARE Center, Laboratory of Oceanology, University of Liège, Sart Tilman B6c, 4000 Liège, Belgium \\ ${ }^{b}$ STARESO, BP 33, F20260 Calvi, France \\ ${ }^{\mathrm{c}}$ Institut français de recherche pour l'exploitation de la mer (Ifremer), ZI FURIANI, 20600, Bastia, France \\ *: Corresponding author: Amandine Collignon, tel.: +32 496430585 ; fax: +32 43665147 ; email address : \\ Amandine.collignon@ulg.ac.be \\ JH.Hecq@Ulg.ac.be ; Francois.Galgani@ifremer.fr ; fcollard@doct.ulg.ac.be ; A.Goffart@ulg.ac.be
}

\begin{abstract}
:
The annual variation in neustonic plastic particles and zooplankton was studied in the Bay of Calvi (Corsica) between 30 August 2011 and 7 August 2012. Plastic particles were classified into three size classes, small microplastics $(0.2-2 \mathrm{~mm})$, large microplastics $(2-5 \mathrm{~mm})$ and mesoplastics $(5-10 \mathrm{~mm})$.

$74 \%$ of the 38 samples contained plastic particles of varying composition: e.g. filaments, polystyrene, thin plastic films. An average concentration of 6.2 particles/100 $\mathrm{m} 2$ was observed. The highest abundance values (69 particles/100 m2) observed occurred during periods of low offshore wind conditions. These values rose in the same order of magnitude as in previous studies in the North Western Mediterranean.

The relationships between the abundance values of the size classes between zooplankton and plastic particles were then examined. The ratio for the intermediate size class $(2-5 \mathrm{~mm})$ reached 2.73 . This would suggest a potential confusion for predators regarding planktonic prey of this size class.
\end{abstract}

\section{Highlights}

$74 \%$ of the 38 samples contained plastic particles. An average concentration of 6.2 particles $/ 100 \mathrm{~m}^{2}$ was observed. Ratio (n plastic)/(n zooplankton) for intermediate class size (2$5 \mathrm{~mm}$ ) reached 2.73. This suggest a potential confusion for predators regarding these planktonic prey.

Keywords: Microplastic particles ; Mesoplastic particles ; Neuston ; Mediterranean Sea 


\section{Introduction}

Many studies in recent decades have reported that plastics are very persistent (Pruter, 1987) and represent the main component of marine garbage (e.g., Barnes et al., 2010; Ivar do Sul et al., 2009; Matsumura and Nasu, 1997; Storrier et al., 2007).

It has been shown that large plastic items break up into smaller pieces in the marine environment (Andrady, 2011; Cole et al., 2011; Thompson et al., 2004; Eriksson and Burton, 2003) with dimensions as small as a few micrometres. The most common small fragments are mesoplastic (defined as 5 to $10 \mathrm{~mm}$ ), large microplastic (defined as 2 to $5 \mathrm{~mm}$ ) and small microplastic particles (defined as 0.2 to $2 \mathrm{~mm}$ ). Fragmented particles contribute to the majority of microplastics and have various origins (Gregory and Andrady, 2003). These particles result from the mechanical, biological, photic and thermal degradation of macrofragments (Andrady, 2011). However, these degradation processes in water are particularly slow due to reduced UV exposure and lower temperatures in the water compared to on the land (Barnes et al., 2009; Rayan et al., 2009).

Plastic particles have invaded the marine environment and are widely distributed throughout the world's oceans and seas, including the water column and marine sediments reaching as far as the abyssal depths. Moreover, the particles mainly accumulate in the regions of convergence and in the gyres (e.g., Moore et al., 2001; Thomson et al., 2004; Law et al., 2010; Andrady, 2011; Claessens et al., 2011; Collignon et al., 2012, Van Cauwenberghe et al., 2013). The majority of these particles are of a density lower than that of sea water and they may accumulate in the neuston, which occupies the top few centimetres of the surface layer of the water.

It is becoming increasingly apparent that these plastic particles have a significant impact on marine flora and fauna (e.g., Anastasopoulou et al., 2013; Cole et al., 2013; Farrell and Nelson, 2013; von Moos et al., 2012; Graham and Thomson, 2009; Fossi et al., 2012; Carpenter et al., 
1972). The smaller the particles, the more likely they are to be ingested by marine life (Carson, 2013; von Moos et al., 2012; Andrady, 2011; Ng and Obbard, 2006). However, the impact of microplastic particles on zooplankton remains poorly investigated.

In the Mediterranean Sea, the only data published on neustonic microplastics (0.3 to $5 \mathrm{~mm}$ ) relates to one study performed in the North Western Mediterranean in 2010 (Collignon et al., 2011).

Even though the use of many time series makes it possible to describe the seasonal variations in the plankton, there is no actual data describing the seasonal variations in microplastics and the neuston, either in the Mediterranean Sea or in other basins.

In this context, the present study aimed to analyse the abundance within specified size classes of small micro-, large micro- and meso-plastic neustonic particle and neustonic zooplankton over a one year period in the region of the Bay of Calvi (Corsica). The study was carried out at the marine station STARESO $\left(42^{\circ} 35^{\prime} 7,80^{\prime \prime} \mathrm{N}\right.$ and $8^{\circ} 43^{\prime} 46,37^{\prime \prime} \mathrm{E}$ - North Western Mediterranean Basin) (Fig. 1), where an interdisciplinary programme of marine ecosystem monitoring has acquired multiparametric data series. The station is recognized as a reference point for the west coast of Corsica and is an area with no developed urban zone, heavy industry or important fluvial inputs. 


\section{Materials and methods}

Between 30 August 2011 and 07 August 2012, a series of 38 neuston samples were collected in the Bay of Calvi, semi-monthly except in September, when a larger number of samples were collected (Tab. 1). Neuston samples were collected using a floating wp2 net with a $0.2 \mathrm{~mm}$ mesh size. The dimensions of the rectangular net mouth were $0.6 \times 0.25 \mathrm{~m}$. The trawl sampled the 0.2 first metres of the sea surface at an average speed of $2.5 \mathrm{~km} / \mathrm{h}$ for a period of 20 minutes for each sample. All samples were concentrated at $0.20 \mathrm{l}$ and were fixed in $2.5 \%$ formalin.

After removing natural debris in the laboratory, samples were transferred into graduated cylinders in order to separate by gravity plastic particles from zooplankton. The zooplankton sank and was deposited as the majority on the bottom of the tubes, whereas the plastic fragments floated. Both elements were examined, sorted, measured and classified into 3 size classes $(0.2-2 \mathrm{~mm}, 2-5 \mathrm{~mm}$ and 5-10 $\mathrm{mm})$ under a binocular microscope. The presence of fouling organisms was also noted.

The zooplankton volume or biovolume was measured after 24 hours of sedimentation in these graduated cylinders. The results were expressed in $\mathrm{ml} / 100 \mathrm{~m}^{2}$.

The abundance of zooplankton organisms was determined for each size class considered in such a way as to establish the plastic/zooplankton ratio. This ratio indicates the potential level of contamination for the consumer.

Wind speed and velocity were measured daily at the STARESO Station during the surveys. (Unpublished data) 


\section{Results and discussion}

\section{Abundance and composition of plastic particles}

During the period of study, plastic particles were found to be present within the neuston in $74 \%$ of the 38 samples. The abundance values, on the other hand, varied according to the particle size range and the sampling period. The highest abundance values were observed during the summer. Values decreased in autumn to reach levels close to 0 in winter and spring. This situation was similar for all the size classes considered.

The annual average of the abundance of total plastic particles $(<10 \mathrm{~mm})$ on the surface layer was 6.2 particles per $100 \mathrm{~m}^{2}$. The highest values were observed on September 302011 and on April 102012 (respectively 56.7 and 68.8 particles/100 $\mathrm{m}^{2}$ ) and the lowest in winter (0 particles $/ 100 \mathrm{~m}^{2}$ ). These values are twice as low as those previously observed in the whole North-Western Mediterranean Basin (Collignon et al., 2012) and 6 times lower than those observed in the North Pacific Gyre (Moore et al., 2001).

The large microplastic particles (size class 2 to $5 \mathrm{~mm}$ ) were found to be the most abundant. They represented $54 \%$ of the total amount of plastic particles with an annual average abundance of 3.4 particles $/ 100 \mathrm{~m}^{2}$. (Tab. 1 and Fig. 2). The highest monthly average abundance values of large microplastic particles (5 to $10 \mathrm{~mm}$ ) were observed in September and April (respectively $5.5 \pm$ 9.78 and $13.2 \pm 22.8$ particles $/ 100 \mathrm{~m}^{2}$ ) (Fig. 3).

The small microplastic and mesoplastic particles followed the same trends in variation, but they were less abundant and represented 28 and $18 \%$ of the total amount of plastic particles, with an annual average abundance of 1.7 and 1.1 particles $/ 100 \mathrm{~m}^{2}$ respectively (Fig. 3-A).

In the same samples, plastic particles larger than $10 \mathrm{~mm}$ were also observed (with abundance values of around 1.3 particles $/ 100 \mathrm{~m}^{2}$ ). 


\section{Relationship between plastic particles and wind speed and direction}

As most plastic particles are buoyant (Derraik, 2002), they can be transported by currents and winds, resulting in their widespread presence across the oceans and seas.

The effect of wind mixing on the vertical distribution of buoyant plastic debris has already been suggested (Lattin et al. 2004). In their study in the North Western Mediterranean, Collignon et al. (2012) observed that concentrations of neustonic plastic particles were 5 times higher before than after a strong wind event. The wind increased the mixing and the vertical distribution of plastic particles in the upper layers of the water column. Kukulka et al. (2012) found an inverse relationship between wind speed and concentration of plastic particles on the sea surface in the North Atlantic Subtropical Gyre. Based on a one-dimensional column model, the authors estimated that, under average wind conditions, $54 \%$ of plastic particles are mixed below surface tow depths.

During the present study, no significant correlation was observed between the abundance of small plastic particles $(<10 \mathrm{~mm})$ and wind speed (Fig. 4-A). However, we did not observe very high windspeeds or storm conditions during this sampling period and the wind remained below the threshold that would have induced particle mixing. On the other hand, analysis of the wind direction indicated that particles were more abundant as a result of North East winds causing the accumulation of plastic particles, inside the Bay of Calvi (Fig. 4-B). Furthermore, we hypothesized that winds blowing in this direction would maintain in the bay a large quantity of terrestrial input containing plastics. This hypothesis was confirmed by the presence of numerous terrestrial fragments.

\section{Abundance and composition of neustonic zooplankton}


Generally, the small fragments of plastic found in the water column and in the neuston, presented the same size range as the zooplankton $(0.2-10 \mathrm{~mm})$. The zooplankton community plays a key role in the marine foodweb. It feeds on plankton ten times smaller than itself and it is a food resource for small pelagic fishes, crustaceans and others.

During the present study, the neustonic zooplankton biovolume fluctuated between 0.8 and 16.0 $\mathrm{ml} / 100 \mathrm{~m}^{2}$, with an average of $5.5 \mathrm{ml} / 100 \mathrm{~m}^{2}$. The biovolume was maximal at the end of the summer, in September (Tab. 1).

The annual average abundance of the total neustonic zooplankton organisms $(<10 \mathrm{~mm})$ was 11206 individuals per $100 \mathrm{~m}^{2}$. The highest abundance values were observed in September 2011 and April 2012 (respectively 80113 and 98561 individuals $/ 100 \mathrm{~m}^{2}$ ), and the lowest in March (342 individuals $/ 100 \mathrm{~m}^{2}$ ). There was no significant correlation between the zooplankton and microplastic particles found in the neuston; their presence varied independently. Unlike microplastics, zooplankton are relatively little affected by wind stress and mixing, and they can swim to maintain their distribution in the neustonic layers.

The neustonic zooplankton size class ranging from to 0.2 to $2 \mathrm{~mm}$ was mainly composed of copepods and cladoceran organisms, which were largely dominant. They represented $96 \%$ of the total amount of zooplankton, with an annual average abundance of 10706 individuals $/ 100 \mathrm{~m}^{2}$. (Fig. 2-B). The highest monthly average abundance values were observed in April and September (respectively $39033 \pm 51633$ and $17661 \pm 26759$ particles/100 m²) (Fig. 3-B).

For the size class ranging from 2 to $5 \mathrm{~mm}$, constituted by larvaceans, mollusks (Creseis sp) and ichtyoplankton, the highest monthly abundance values were observed during August and September (respectively $1074 \pm 496$ and $1079 \pm 882$ particles $/ 100 \mathrm{~m}^{2}$ ) (Fig. 3 -C). 
Invertebrates, representing different feeding strategies, are capable of ingesting these microscopic plastic particles. Polychaetes, bivalves, echinoderms and copepods will all, during at least one life stage, take up microplastics from the environment (Cole et al., 2013; Graham and Thompson, 2009; Thompson et al., 2004; Ward and Shumway, 2004). Once ingested, a proportion of these microplastics are eliminated in faecal pellets (Frost, 1977), which then sink into the deeper layers of the sediment.

In the present case, the average number ratio between the abundance of small microplastics and zooplankton (e.g., copepods, cladocerans) $(0.2-2 \mathrm{~mm}$ ) remained below the value of 0.002 for the whole study. This value is relatively low compared to other regions (Moore et al. 2001; Lattin et al., 2004). This could imply that neustonic zooplankton rarely encounter or interact with microplastic debris.

On the other hand, for the large microplastics and zooplankton (decapod larvae, fish larvae) from the size class between 2 and $5 \mathrm{~mm}$, the ratio reached 2.63. Because of these small dimensions, microplastics become available for ingestion by organisms commonly unaffected by the larger marine debris. They also present a wide variety of colours, sizes, and shapes of plastic fragments. Consequently, microplastics probably mimic a wide range of natural food sources for these organisms and may both compete with and threaten the plankton.

Small plastic particles are already known to be ingested via filter-feeding (Browne et al., 2008) and deposit-feeding (Graham and Thompson, 2009). More recently, small plastic particles have been encountered in the guts of various planktivorous fishes (Foekema et al., 2013; Davidson et al., 2010; Boerger et al., 2010) because these fishes cannot differentiate plastic fragments from plankton. In the Mediterranean Sea, plastic fragments have recently been observed inside five deepwater fishes in the Mediterranean Sea (Anastasopoulou et al., 2013). 
Cole et al. (2013) demonstrated in the laboratory that ingestion of small microplastic particles by copepods has a negative impact upon zooplankton function and health. The size class used in that study $(<10 \mu \mathrm{m})$ was not considered for inclusion here because of our chosen methodology.

\section{Fouling of microparticles}

During the present study, epiphytic fouling was observed in approximately $22 \%$ of the plastic particles examined. This percentage was higher during summer (in August to September). These epiphytes were mainly small algae and foraminiferae (Fig. 5). Because of their durability and associated long lifespan, floating debris can also act as a vector for invasive species (Barnes and Fraser, 2003; Barnes and Milner, 2005; Majer et al., 2012). Floating debris has been implicated as a vector for transportation of harmful algal species (Masó et al., 2007).

Small plastic particles also provide a substrate for microbes that lasts much longer than most natural floating substrates and, consequently, the particles can function as an artificial "microbial reef" (Zettler, 2013).

As fouling increases the density of these plastic particles, this can cause them to sink to the sea floor and to contribute to the amount of small plastic particles present on the ground and in the sediment.

The present study provides a preliminary understanding of microplastic pollution in the North Western part of the Mediterranean region by reporting the concentration levels and temporal distribution of microplastics in a region poorly impacted by human activity. 


\section{Acknowledgements}

This work was supported by the F.R.S.-FNRS (Fonds de la Recherche Scientifique), the FRIA (Fonds pour la Recherche dans l'Industrie et l'Agriculture) and the IFREMER (Institut Français de Recherche pour l'Exploitation de la Mer). J.-H. Hecq is senior research associate, FRS. We thank the crew of STARESO. We thank also the ISLV Editing and Translation Services of the University of Liège for improving the language of the manuscript. 


\section{Bibliography}

Anastasopoulou, A., Mytilineou, C., Smith, C.J., Papadopoulou, K.N., 2013. Plastic debris ingested by deep-water fish of the Ionian Sea (Eastern Mediterranean). Deep Sea Res. Part I: Oceanogr. Res. Pap74: 11-13, 2013.

Andrady, A. L. 2011. Microplastics in the marine environment. Mar. Pollut. Bull. 62, 15961605.

Arthur, C., Baker, J.,Bamford, H., (Eds.), 2009. Proceedings of the International Research Workshop on the Occurrence, Effects and Fate of Microplastic Marine Debris. Sep 9-11, 2008. NOAA Technical Memorandum NOS-OR\&R-30. NOAA, Silver Spring 530pp.

Barnes, D. K. A.; Galgani, F.; Thompson, R. C.; Barlaz, M. 2009. Accumulation and fragmentation of plastic debris in global environments. Philos. Trans. R. Soc. B-Biol. Sci. 364(1526), 1985-1998.

Barnes, D.K., Walters, A., Gonçalves, L., 2010. Macroplastics at sea around Antarctica. Mar. Environ. Res. 70, 250-252.

Boerger, C. M.; Lattin, G. L.; Moore, S. L.; Moore, C. J., 2010. Plastic ingestion by planktivorous fishes in the North Pacific Central Gyre. Mar. Pollut. Bull. 60 (12), 2275-2278.

Browne, M.A., Dissanayake, A., Galloway, T.S., Lowe, D.M., 2008. Ingested microscopic plastic translocates to the circulatory system of the mussel, Mytilus edulis. Environ. Sci. 
Technol. 42 (13), 5026-5031.

Carpenter, E.J., Anderson, S.J., Harvey, G.R., Miklas, H.P., Peck, B.B., 1972. Polystyrene spherules in coastal waters. Science $175,749-750$.

Carson, H.S., 2013. The incidence of plastic ingestion by fishes: From the prey's perspective. Mar. Pollut. Bull. 74(1), 170-174

Claessens, M., De Meester, S., Van Landuyt, L., De Clerck, K., Janssen, C.R., 2011. Occurrence and distribution of microplastics in marine sediments along the Belgian coast. Mar. Pollut. Bull. 62, 2199e2204.

Collignon, A., Hecq, J. H., Galgani, F., Voisin, P., Collard, F.,Goffart, A. 2012. Neustonic microplastic and zooplankton in the North Western Mediterranean Sea. Marine Pollution Bulletin. 64, 861-864.

Cole, M., Lindeque, P., Halsband, C., Galloway, T.S., 2011. Microplastics as contaminants in the marine environment: a review. Mar. Pollut. Bull. 62, 2588-2597.

Cole, M., Lindeque, P., Fileman, E., Halsband, C., Goodhead, R., Moger, J., Galloway, T.S., 2013. Microplastic ingestion by Zooplankton. Environmental Science and Technology. 47, $6646-6655$.

Davison, P.; Asch, R. G. 2011. Plastic ingestion by mesopelagic fishes in the North Pacific Subtropical Gyre. Mar. Ecol.-Prog. Ser. 432, 173-180. 
Derraik, J.G.B., 2002. The pollution of the marine environment by plastic debris: a review. Mar. Pollut. Bull. 44, 842-852.

Endo, S., Yuyama, M., Takada, H. 2013. Desorption kinetics of hydrophobic organic contaminants from marine plastic pellets Mar. Pollut. Bull. 74(1), 125-131.

Eriksson, C.; Burton, H. 2003. Origins and biological accumulation of small plastic particles in fur seals from Macquarie Island. Ambio. 32(6), 380-384.

Farrell, P., Nelson, K., 2012. Trophic level transfer of microplastic: Mytilus edulis (L.) 905 to Carcinus maenas (L.). Environ. Pollut. 177, 1-3.

Foekema, E. M., De Gruijter, C., Mergia, M. T., van Franeker, J. A. Murk, A. J., Koelmans, A. A.,2013. Plastic in North Sea Fish. Environ. Sci. Technol. 47(15), 8818-8824

Fossi, M.C., Panti, C., Guerranti, C., Coppola, D., Giannetti, M., Marsili, L., Minutoli, R., 2012. Are baleen whales exposed to the threat of microplastics? A case study of the Mediterranean fin whale (Balaenoptera physalus). Mar. Pollut. Bull. 64, 2374-2379.

Frost, B. W. 1977. Feeding behavior of Calanus pacificus in mixtures of food particles. Limnology and Oceanography 22:472-491.

Galgani, F., Leaute, J.P., Moguedet, P., Souplet, A., Verin, Y., Carpentier, A., Goraguer, H., Latrouite, D., Andral, B., Cadiou, Y., Mahe, J.C., Nerisson P., 2000. Litter on the Sea Floor 
Along European Coasts. Mar. Pollut. Bull. 40(6), 516-527.

Graham, E., Thompson, J., 2009. Deposit- and suspension-feeding sea cucumber (Echinodermata) ingest plastic fragments. J. Exp. Mar. Biol. Ecol. 368, 22-29.

Gregory, M.R., Andrady, A.L., 2003. Plastics in the marine environment. In: Andrady, Anthony.L. (Ed.), Plastics and the Environment. John Wiley and Sons, ISBN 0-471-095206, (2003).

Ivar do Sul, J.A., Spengler, A., Costa, M., 2009. Here, there and everywhere. Small plastic fragments and pellets on beaches of Fernando de Noronha (Equatorial Western Atlantic). Mar. Pollut. Bull. 58, 1229-1244.

Kukulka, T., Proskurowski, G., Morét-Ferguson, S., Meyer, D.W., Law, K.L., 2012. The effect of wind mixing on the vertical distribution of buoyant plastic debris. Geophys. Res. Lett. 39, L07601.

Lattin, G.L., Moore, C.J., Zellers, A.F., Moore, 994 S.L., Weisberg, S.B., 2004. A comparison of neustonic plastic and zooplankton at different depths near the southern California shore. Mar. Pollut. Bull. 49, 291-294.

Law, K.L., Moret-Ferguson, S., Maximenko, N.A., Proskurowski, G., Peacock, E.E., Hafner, J., Reddy, C.M., 2010. Plastic accumulation in the North Atlantic subtropical gyre. Science $329,1185-1188$. 
Masó, M.; Garcés, E.; Page s, F.; Camp, J. 2007. Drifting plastic debris as a potential vector for dispersing Harmful Algal Bloom (HAB) species. Sci. Mar.. 67(1), 107-111.

Matsumura, S., Nasu, K., 1997. Distribution of floating debris in the north Pacific Ocean: sighting surveys 1986-1991, in: Coe, J.M. et al. (Ed.) (1997). Marine debris: sources, impacts, and solutions. Springer Series on Environ. Manage. pp. 15-24.

Moore, C. J., Moore, S. L., Leecaster, M. K., Weisberg, S. B. 2001. A comparison of plastic and plankton in the North Pacific central gyre. Mar. Pollut. Bull., 42, 1297-1300.

Murray, F.; Cowie, P. R., 2011. Plastic contamination in the decapod crustacean Nephrops norvegicus (Linnaeus, 1758). Mar. Pollut. Bull., 62, (6), 1207-1217.

Ng, K.L.; Obbard, J.P., 2006. Prevalence of microplastics in Singapore's coastal marine environment. Mar. Pollut. Bull. 52, 761-767.

Pruter, A. T., 1987. Sources, quantities and distribution of persistent plastics in the marine environment. Mar. Pollut. Bull. 18 (6B), 305-310.

Ryan, P. G.; Moore, C. J.; van Franeker, J. A.; Moloney, C. L. 2009.Monitoring the abundance of plastic debris in the marine environment. Philos. Trans. R. Soc. B-Biol. Sci., 364 (1526), 1999-2012.

Schulz, M., Neumann, D., Fleet, D., Matthies, M. 2013. A multi-criteria evaluation system for marine litter pollution based on statistical analyses of OSPAR beach litter monitoring 
time series. Marine Mar. Environ. Res., in press. doi: 10.1016/j.marenvres.2013.08.013.

Storrier, K.L., McGlashan, D.J., Bonellie, S., Velander, K., 2007. Beach litter deposition at a selection of beaches in the Firth of Forth, Scotland. J. Coastal Res. 23, 813-822.

Thompson, R.C., Olsen, Y., Mitchell, R.P., Davis, A., Rowland, S.J., John, A.W.G., McGonigle, D., Russell, A.E., 2004. Lost at sea: Where is all the plastic? Science, 304, 838.

Van Cauwenberghe L., Vanreusel A., Mees J. , Janssen C. R. 2013 Microplastic pollution in deep-sea sediments. Environmental Pollution. In press

Van Franeker, J. A.; Blaize, C.; Danielsen, J.; Fairclough, K.; Gollan, J.; Guse, N.; Hansen, P.L.; Heubeck, M.; Jensen, J.-K.; Le Guillou, G.; Olsen, B.; Olsen, K.-O.; Pedersen, J.; Stienen, E. W. M., Turner, D. M. 2011. Monitoring plastic ingestion by the northern fulmar Fulmarus glacialis in the North Sea. Environ. Pollut.. 159(10), 2609-2615.

von Moos, N., Burkhardt-Holm, P., Köhle, A., 2012. Uptake and effects of microplastics on cells and tissue of the blue mussel Mytilus edulis L. after an experimental exposure. Environ. Sci. Technol. 46, 11327-11335.

Zettler, E. R., Mincer, T. J., Amaral-Zettler, L. A. 2013. Life in the "Plastisphere": Microbial Communities on Plastic Marine Debris. Environ. Sci. Technol. 47 (13),7137-7146. 
Table 1: Biovolumes, abundance and \% of fouling of neustonic zooplankton and plastic particles

Fig. 1: Location of the neustonic sampling transect in the Bay of Calvi, Corsica (North-Western Mediterranean Sea)

Fig. 2: Proportion of the total abundance of plastic particles (left) and of neustonic zooplankton

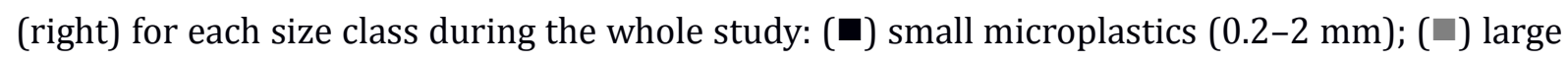
microplastics (2-5 mm); and ( $\square$ mesoplastics (5-10 mm).

Fig. 3: (A) Monthly average abundance and composition of plastic debris on beaches by size class: (ロ) small microplastics $(0.2-2 \mathrm{~mm}),(\square)$ large microplastics $(2-5 \mathrm{~mm})$, and $(\square)$ mesoplastics (5-10 $\mathrm{mm})$.

Monthly average abundance of neustonic zooplankton: (B) for size class: ( $\square$ ) 0.2-2 mm and (C) for size classes ( $\square$ ) 2-5 mm, and ( ) 5-10 mm.

Fig. 4. Abundance of plastic particles $(<10 \mathrm{~mm})$ in function of the Wind Speed (left) or direction (right)

Fig. 5. Fouling of small plastic particles by organisms 


\begin{tabular}{|c|c|c|c|c|c|c|c|c|c|c|c|c|}
\hline & \multirow{2}{*}{\begin{tabular}{|c|} 
Biovolume \\
$\mathrm{ml} / 100 \mathrm{~m}^{2}$ \\
\end{tabular}} & \multicolumn{3}{|c|}{ Particles $\leq 2 \mathrm{~mm}$} & \multicolumn{3}{|c|}{ Particles $2 \mathrm{~mm}$ to $\leq 5 \mathrm{~mm}$} & \multicolumn{3}{|c|}{ Particles $5 \mathrm{~mm}$ to $\leq 10 \mathrm{~mm}$} & \multirow{2}{*}{\begin{tabular}{|c|} 
Particles $>10 \mathrm{~mm}$ \\
$\mathrm{n} / \mathbf{1 0 0 \mathrm { m } ^ { 2 }}$
\end{tabular}} \\
\hline & & & $n / 100 m^{2}$ & $\mathrm{n} / 100 \mathrm{~m}^{2}$ & \% Fouling & $n / 100 m^{2}$ & $\mathrm{n} / 100 \mathrm{~m}^{2}$ & \% Fouling & $n / 100 m^{2}$ & $\mathrm{n} / 100 \mathrm{~m}^{2}$ & \begin{tabular}{|l|} 
\% Fouling \\
\end{tabular} & \\
\hline & & Plankton & Plankton & Microplastic & Microplastic & Plankton & Microplastic & Microplastic & Plankton & Mesoplastic & Mesoplastic & Plastic \\
\hline 1 & 30-Aug-11 & 15.00 & 857 & 0.00 & & 588 & 0.00 & & 1.35 & 0.00 & & 0.00 \\
\hline 2 & 31-Aug-11 & 4.00 & 3728 & 0.00 & & 1580 & 0.00 & & 0.94 & 0.00 & & 0.00 \\
\hline 3 & 31-Aug-11 & 5.00 & 4642 & 0.00 & & 1054 & 2.00 & 0 & 1.44 & 0.00 & & 0.00 \\
\hline 4 & 01-Sep-11 & 2.75 & 1223 & 1.50 & 17 & 688 & 3.75 & 20 & 0.48 & 2.75 & 73 & 8.50 \\
\hline 5 & 01-Sep-11 & 16.00 & 79680 & 10.00 & 20 & 433 & 19.00 & 34 & 0.01 & 8.50 & 53 & 11.00 \\
\hline 6 & 02-Sep-11 & 5.00 & 5730 & 0.50 & 100 & 2868 & 1.00 & 0 & 0.08 & 0.00 & & 0.00 \\
\hline 7 & 03-Sep-11 & 4.00 & 5841 & 0.00 & & 532 & 0.00 & & 0.14 & 0.00 & & 0.00 \\
\hline 8 & 04-Sep-11 & 3.00 & 4343 & 0.00 & & 1080 & 1.50 & 0 & 0.47 & 0.00 & & 0.50 \\
\hline 9 & 05-Sep-11 & 5.00 & 2782 & 0.00 & & 1024 & 0.00 & & 0.41 & 0.00 & & 0.00 \\
\hline 10 & 06-Sep-11 & 3.00 & 2801 & 0.00 & & 408 & 0.00 & & 0.31 & 0.00 & & 0.00 \\
\hline 11 & 07-Sep-11 & 8.00 & 6324 & 0.50 & 0 & 2573 & 0.00 & & 0.50 & 0.00 & & 0.50 \\
\hline 12 & 08-Sep-11 & 4.71 & 19351 & 0.00 & & 1327 & 0.00 & & 1.42 & 0.00 & & 0.00 \\
\hline 13 & 21-Sep-11 & 3.5 & 5400 & 2.50 & 30 & 138 & 6.00 & 54 & 0.58 & 3.50 & 36 & 2.50 \\
\hline 14] & 30-Sep-11 & 10.67 & 60792 & 15.33 & 0 & 800 & 29.67 & 26 & 0.96 & 11.67 & 20 & 9.33 \\
\hline 15 & 04-Oct-11 & 4.50 & 6219 & 2.25 & 22 & 133 & 2.50 & 40 & 0.84 & 1.00 & 25 & 0.75 \\
\hline 16 & 18-Oct-11 & 2.50 & 786 & 1.50 & 0 & 61 & 4.50 & 33 & 0.28 & 1.00 & 75 & 0.50 \\
\hline 17 & 02-Nov-11 & 8.50 & 2299 & 1.25 & 60 & 316 & 1.75 & 71 & 1.06 & 0.25 & 0 & 0.25 \\
\hline 18 & 15-Nov-11 & 7.50 & 1606 & 0.25 & 0 & 180 & 2.25 & 22 & 2.04 & 1.00 & 75 & 1.50 \\
\hline 19 & 06-Dec-11 & 4.00 & 4894 & 1.00 & 25 & 169 & 1.00 & 0 & 0.93 & 0.00 & & 0.00 \\
\hline 20 & 13-Dec-11 & 4.00 & 6764 & 0.25 & 100 & 354 & 0.25 & 0 & 1.12 & 0.00 & & 0.00 \\
\hline 21 & 05-Jan-12 & 3.00 & 3677 & 0.50 & 0 & 469 & 0.50 & 50 & 0.19 & 0.00 & & 0.00 \\
\hline 22 & 16-Jan-12 & 14.00 & 9901 & 0.00 & & 1036 & 0.00 & & 0.86 & 0.00 & & 0.00 \\
\hline 23 & 07-Feb-12 & 0.75 & 4640 & 0.00 & & 13 & 0.00 & & 0.84 & 0.00 & & 0.00 \\
\hline 24 & 20-Feb-12 & 3.50 & 2000 & 0.50 & 0 & 26 & 0.25 & 0 & 0.03 & 0.25 & & 0.00 \\
\hline 25 & 15-Mar-12 & 2.50 & 2371 & 0.00 & & 2 & 0.00 & 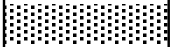 & 0.05 & 0.00 & & 0.00 \\
\hline 26 & 26-Mar-12 & 2.50 & 341 & 0.50 & 0 & 1 & 0.75 & 0 & 0.05 & 0.00 & 0 & 0.00 \\
\hline 27| & 10-Apr-12 & 9.00 & 12659 & 21.75 & 13 & 0 & 39.5 & 18 & 0.67 & 7.50 & 10 & 10.00 \\
\hline 28 & 16-Apr-12 & 8.00 & 5880 & 0.00 & & 0 & 0.00 & & 0.00 & 1.00 & 50 & 0.00 \\
\hline 29 & 24-Apr-12 & 6.75 & 98560 & 0.00 & & 1 & 0.00 & & 0.08 & 0.00 & & 0.00 \\
\hline 30 & 08-May-12 & 2.50 & 2842 & 0.50 & 0 & 19 & 0.25 & 0 & 0.07 & 0.00 & & 0.00 \\
\hline 31 & 23-Мау-12 & 4.50 & 3113 & 0.25 & 0 & 1 & 0.25 & 0 & 0.11 & 0.25 & 0 & 0.25 \\
\hline 32 & 24-May-12 & 7.00 & 6977 & 0.50 & 100 & 16 & 1.00 & 0 & 0.21 & 0.00 & & 0.50 \\
\hline 33 & 25-May-12 & 10.00 & 4700 & 1.00 & 100 & 16 & 1.50 & 0 & 0.22 & 1.00 & 0 & 2.00 \\
\hline 34 & 05-Jun-12 & 5.00 & 8740 & 0.75 & 0 & 73 & 1.75 & 14 & 0.05 & 0.50 & 0 & 0.25 \\
\hline 35 & 19-Jun-12 & 1.50 & 2630 & 0.00 & & 225 & 0.25 & 100 & 0.03 & 0.00 & & 0.00 \\
\hline 36 & 10-Jul-12 & 1.50 & 1406 & 0.75 & 0 & 52 & 0.50 & 0 & 0.05 & 0.00 & & 0.25 \\
\hline 37 & 24-Jul-12 & 3.00 & 2208 & 1.00 & 0 & 362 & 5.00 & 0 & 6.00 & 1.50 & 0 & 0.00 \\
\hline 38 & 07-Aug-12 & 3.00 & 8104 & 0.25 & 0 & 357 & 1.75 & 0 & 12.75 & 1.00 & 25 & 0.00 \\
\hline
\end{tabular}




\section{Figure1}

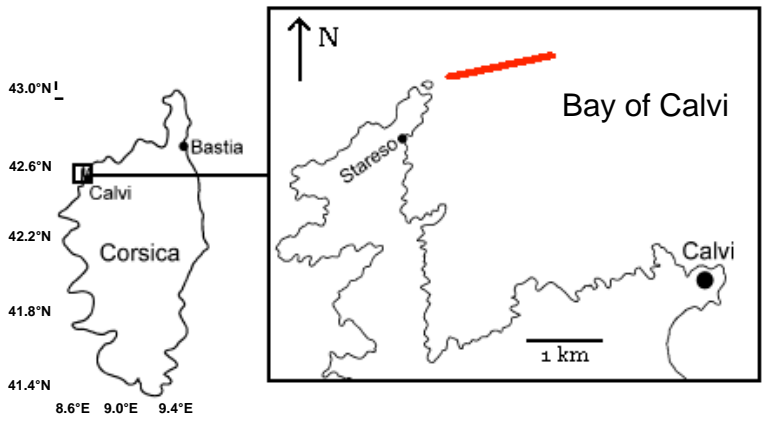


Figure $3 ð \mathrm{BC}$

A. 45

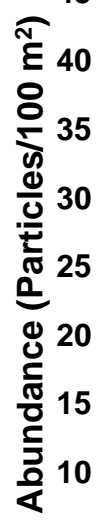

B. $\begin{array}{r}100000 \\ 90000\end{array}$

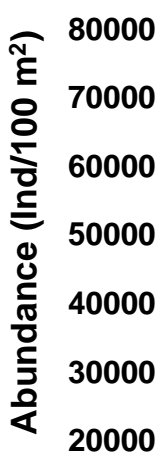

10000

0
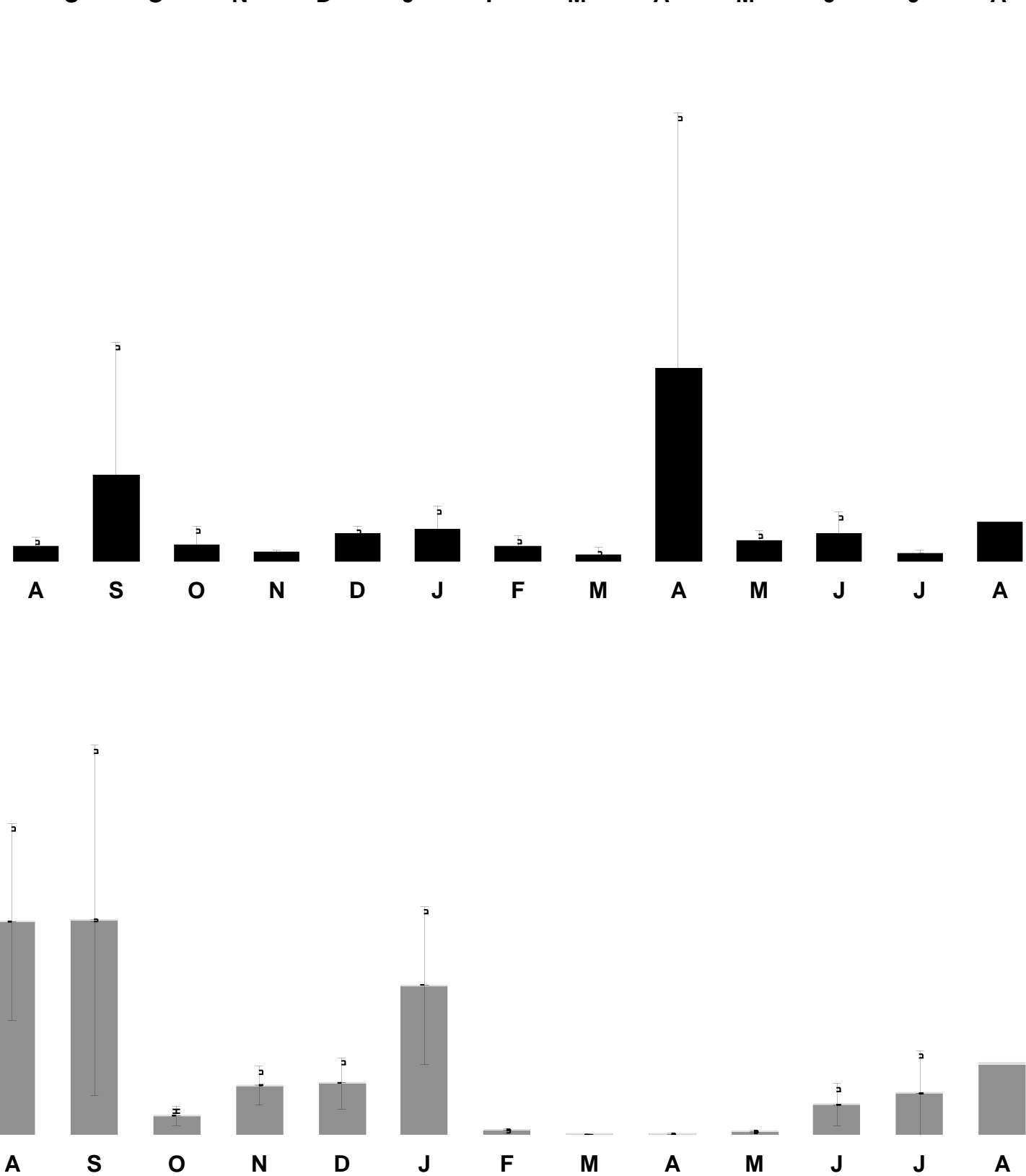

M

A

C. 2500

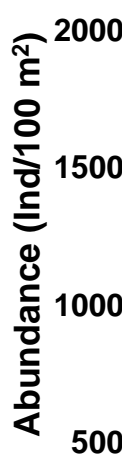

0

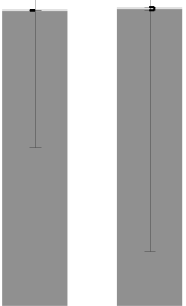

$\begin{array}{llllllllllll} & \text { A } & \text { S } & \text { O } & \text { N } & \text { D } & \text { J } & \text { F } & \text { M }\end{array}$
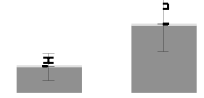

$\begin{array}{llllllllllll} & \text { A } & \text { S } & \text { O } & \text { N } & \text { D } & \text { J } & \text { F } & \text { M }\end{array}$

$\begin{array}{lllllllll} & \text { A } & \text { S } & \text { O } & \text { N } & \text { D } & \text { J } & \text { F } & \text { M }\end{array}$

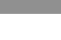

$\begin{array}{llllllllllll} & \text { A } & \text { S } & \text { O } & \text { N } & \text { D } & \text { J } & \text { F } & \text { M }\end{array}$
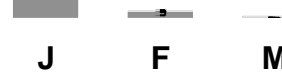


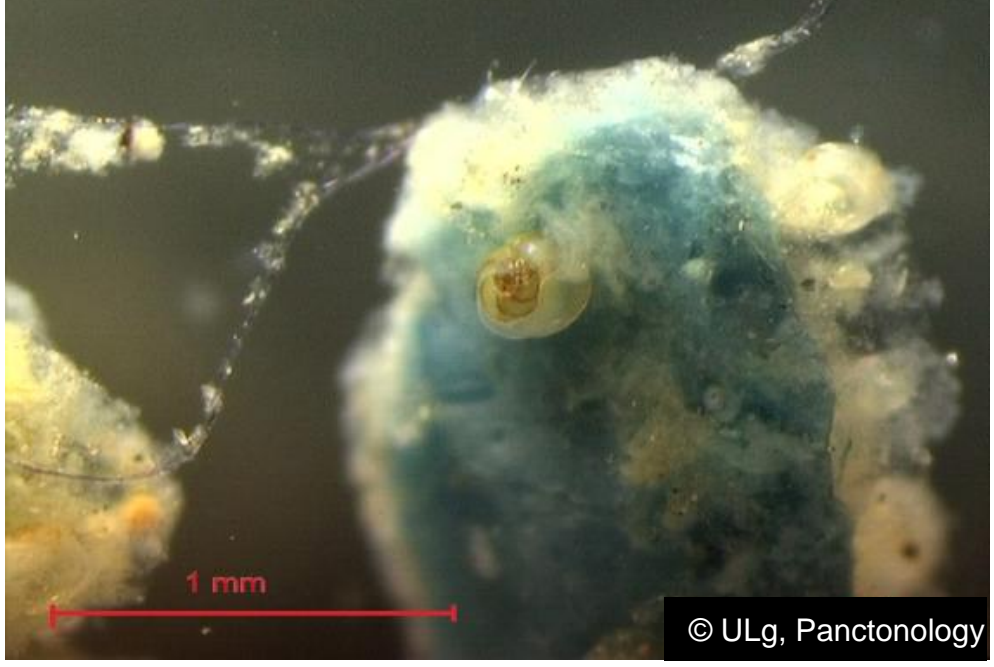

